\title{
Pengaruh Penyuluhan Mengenai Imunisasi terhadap Pengetahuan dan Sikap Ibu di Desa Sukarapih Kec. Sukasari
}

\author{
Reizza Dwitara Pramodya Septiarini ${ }^{1}$, Ari Indra Susanti², Sefita Aryuti Nirmala ${ }^{3}$ \\ ${ }^{1}$ Program Studi Kebidanan Fakultas Kedokteran Universitas Padjadjaran \\ ${ }^{2}$ Departemen Ilmu Kesehatan Masyarakat Fakultas Kedokteran Universitas Padjadjaran \\ ${ }^{3}$ Departemen Ilmu Epidemiologi dan Biostatistik Fakultas Kedokteran Universitas Padjadjaran
}

\begin{abstract}
Abstrak
Kegiatan imunisasi merupakan salah satu cara untuk mencegah terjadinya penyakit tertentu, selain bermanfaat imunisasi juga memberikan efek samping yang dikenal dengan Kejadian Ikutan Pasca Imunisasi (KIPI). Berdasarkan Riskesdas 2013 didapatkan bahwa dari 91,3\% anak di Indonesia yang pernah diimunisasi, terdapat 33,4\% yang pernah mengalami KIPI. Keluhan yang sering terjadi adalah kemerahan dan bengkak, sedangkan keluhan demam tinggi dialami 6,8\% anak. Perlu penyuluhan pada masyarakat untuk mengerti akan terjadinya efek samping. Penelitian ini bertujuan untuk mengetahui pengaruh penyuluhan mengenai imunisasi terhadap pengetahuan dan sikap ibu di Desa Sukarapih, Kecamatan Sukasari, Kabupaten Sumedang. Metode penelitian yang digunakan adalah analitik kuasi eksperimen. Populasi dalam penelitian ini adalah seluruh ibu yang memiliki bayi usia 0-10 buan. Sampel yang digunakan yaitu accidental sampling berjumlah 40 orang. Instrumen yang digunakan adalah kuesioner. Hasil penelitian ini menunjukan pengetahuan responden sebelum diberikan penyuluhan imunsasi berada dalam kategori baik sebanyak 45,0\%, sikap responden yang mendukung sebesar 67,5\%. Setelah diberikan penyuluhan terdapat peningkatan pengetahuan dalam kategori baik menjadi $65,0 \%$, sedangkan sikap responden setelah diberikan penyuluha $50,0 \%$ responden memiliki sikap mendukung. Hasil uji wilcoxon menunjukan terdapat pengaruh bermakna penyuluhan terhadap pengetahuan ibu sebelum dan sesudah diberikan penyuluhan $(\mathrm{p}<0,05 \%)$ tetapi tidak terdapat pengaruh bermakna penyuluhan terhadap sikap ibu sebelum dan setelah dilakukan penyuluhan $(p>0,05 \%)$.
\end{abstract}

Kata Kunci : Imunisasi, pengetahuan, penyuluhan, sikap

\section{Effect of Immunization Health Promotion Knowledge and Attitude Women in the Villagesukarapih Kec. Sukasari}

\begin{abstract}
Immunization activites is one of how to prevent certain diseases, other than beneficial but immunization also known side effects known as Genesis Post-Immunization (GPI). By description Riskesdas in 2013 found that $91.3 \%$ of childrens in Indonesia were ever immunized, there are $33.4 \%$ who had ever experienced GPI. A common complaint is redness and swelling, while complaints of high fever experienced by $6.8 \%$ of children. Itdoes needed counseling on the public to understand the occurrence of side effects. This research aims to determine the effect of counseling about immunization againts the mother's knowledge and attitudes on Desa Sukarapih, Kecamatan Sukasari, Kabupaten Sumedang. The method used is analytic quasi-experimental. The population in this study are all mothers with babies aged 0-10 months. The sample used was accidental sampling of 40 people. The instrument used was a questionnaire. These research results to indicate the respondents'knowledge before being given counseling of immmunization be in either category as much as $45.0 \%$, the attitude of the respondents were supportive of $67.5 \%$. After being given counseling there is increasing knowledge in either category became $65.0 \%$, while the attitude of the respondent after being given counseling 50.0\% of respondents have a supportive attitude. Wilcoxon test results showed there is a significant influence on the extension of knowledge of mothers before and after counseling $(p<0.05 \%)$ but there was no significant effect of counseling on maternal attitudes before and after the extension ( $p>0.05 \%)$.
\end{abstract}

Keywords: Immunization, knowledge, counseling, attitude

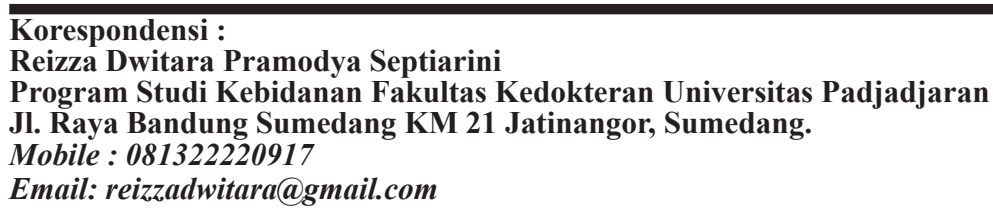




\section{Pendahuluan}

Program imunisasi di Indonesia dimulai pada tahun 1956 dimulai dengan imunisasi cacar di pulau Jawa. Imunisasi tersebut membuahkan hasil sehingga pada tahun 1974 World Health Organization (WHO) menyatakan Indonesia bebas penyakit cacar. Keberhasilan ini memicu pemerintah untuk melakukan imunusasi lainnya sehinggapadatahun 1976mulaidiberikanimunisasi difetri, pertusis, dan tetanus (DPT) sebagai bagian dari Program Pengembangan Imunisasi. ${ }^{1}$

Gambaran dari kegiatan pelayanan imunisasi rutin pada bayi di bawah umur 1 tahun memperlihatkan bahwa cakupannya beberapa provinsi telah bagus. Namun demikian masih ada provinsi-provinsi yang cakupannya masih rendah sehingga masih memerlukan upaya khusus. Berdasarkan data dari Riskesdas 2013 Cakupan imunisasi dasar lengkap bervariasi antar provinsi, yaitu tertinggi di DI Yogyakarta $(83,1 \%)$ dan terendah di Papua $(29,2 \%)$. Secara nasional, terdapat $8,7 \%$ anak $12-23$ bulan yang tidak pernah mendapatkan imunisasi dengan persentase tertinggi di Papua $(36,6 \%)$ dan terendah di DI Yogyakarta $(1,1 \%)$. Sedangkan untuk di Jawa Barat sendiri cakupan imunisasi dasar lengkap adalah 56,6\%, tidak lengkap $35,1 \%$ dan tidak diimunisasi $8,3 \%{ }^{2}$

Selain memiliki manfaat, imunisasi juga menimbulkan efek samping dalam pelaksanaannya. Dalam dunia kesehatan, fenomena ini dikenal juga dengan istilah adverse event atau lebih dikenal dengan kejadian ikutan pasca imunisasi (KIPI). Berdasarkan Riskesdas 2013, didapatkan bahwa dari 91,3 persen anak di Indonesia yang pernah diimunisasi, terdapat 33,4 persen yang pernah mengalami KIPI. Keluhan yang sering terjadi adalah kemerahan dan bengkak, sedangkan keluhan demam tinggi dialami oleh 6,8 persen anak. ${ }^{3}$

Berdasarkan hasil observasi peneliti, meskipun pada kenyataannya sekarang telah banyak ibu yang membawa bayinya ke tenaga kesehatan untuk mendapatkan imuniasi, namun hanya sebagian kecil dari mereka yang diberikan konseling mengenai imunisasi. Akibat dari kurangnya pengetahuan tentang imunisasi banyak ibu yang kemudian panik dan menyalahkan tenaga kesehatan untuk efek samping dari imunisasi yang mungkin bisa terjadi. Pengetahuan ibu terhadap imunisasi adalah merupakan hal yang sangat penting, agar ibu dapat cepat tanggap dan tahu apa yang harus dilakukan ketika timbul efek samping pada anaknya. Hal tersebut nantinya akan berdampak pada pandangan ibu dan kemauan ibu untuk membawa anaknya ke fasilitas kesehatan guna mendapatkan imunisasi. Sehingga akan ada ibu yang berpandangan bahwa imunisasiakan menjadi hal yang merugikan bagi dirinya dan sang anak.

Data yang didapatkan peneliti di lapangan untuk sasaran imunisasi Desa Sukarapih Kecamatan Sukasari Kabupaten Sumedang adalah 134 sedangkan yang dicapai hanya 113 dari lima imunisasi dasar. Berdasarkan data tersebut peneliti ingin mengetahui lebih lanjut lagi mengenai pengetahuan ibu terhadap imunisasi, apakah kurangnya pengetahuan menjadi penyebab tidak tercapainya sasaran imunisasi di Desa Sukarapih.

Dari latar belakang yang telah dipaparkan di atas maka peneliti tertarik untuk meneliti Pengaruh Penyuluhan Mengenai Imunisasi terhadap Pengetahuan dan Sikap Ibu di Desa Sukarapih Kecamatan Sukasari

\section{Metode}

Metode yang digunakan pada penelitian ini adalah metode analitik dengan quasi eksperimental dengan menggunakan one group pretest posttest design untuk membandingkan pengetahuan dan sikap ibu mengenai efek samping imunisasi

Tabel 1. Distribusi Frekuensi Pengentahuan dan Sikap Ibu Sebelum di Berikan Penyuluhan

\begin{tabular}{|c|c|c|c|c|c|c|c|c|}
\hline \multirow{2}{*}{$\begin{array}{l}\text { Sebelum Diberikan } \\
\text { Penyuluhan }\end{array}$} & \multicolumn{8}{|c|}{ Kategori } \\
\hline & \multicolumn{2}{|c|}{ Baik } & \multicolumn{2}{|c|}{ Cukup } & \multicolumn{2}{|c|}{ Kurang } & \multicolumn{2}{|r|}{ Total } \\
\hline \multirow[t]{3}{*}{ Pengetahuan } & $\mathrm{f}$ & $\%$ & $\mathrm{f}$ & $\%$ & $f$ & $\%$ & $\mathrm{f}$ & $\%$ \\
\hline & 18 & 45,0 & 17 & 42,2 & 5 & 12,5 & 40 & 100 \\
\hline & \multicolumn{2}{|c|}{ Mendukung } & & \multicolumn{3}{|c|}{ Tidak Mendukung } & & Total \\
\hline \multirow[t]{2}{*}{ Sikap } & $\mathrm{f}$ & $\%$ & & $\mathrm{f}$ & $\%$ & & $\mathrm{f}$ & $\%$ \\
\hline & 27 & 67,5 & & 13 & 32,5 & & 40 & 100 \\
\hline
\end{tabular}


Reizza Dwitara Pramodya Septiarini : Pengaruh Penyuluhan Mengenai Imunisasi terhadap Pengetahuan dan Sikap Ibu di Desa Sukarapih Kec. Sukasari

Tabel 2. Distribusi Frekuensi Pengetahuan dan Sikap Ibu Sesudah Diberikan Penyuluhan

\begin{tabular}{|c|c|c|c|c|c|c|c|c|}
\hline \multirow{2}{*}{$\begin{array}{l}\text { Setelah Diberikan } \\
\text { Penyuluhan }\end{array}$} & \multicolumn{8}{|c|}{ Kategori } \\
\hline & \multicolumn{2}{|c|}{ Baik } & \multicolumn{2}{|c|}{ Cukup } & \multicolumn{2}{|c|}{ Kurang } & \multicolumn{2}{|r|}{ Total } \\
\hline \multirow[t]{3}{*}{ Pengetahuan } & $\mathrm{f}$ & $\%$ & $\mathrm{f}$ & $\%$ & $\mathrm{f}$ & $\%$ & $\mathrm{f}$ & $\%$ \\
\hline & 26 & 65,0 & 14 & 35 & 0 & 0 & 40 & 100 \\
\hline & \multicolumn{2}{|c|}{ Mendukung } & \multicolumn{4}{|c|}{ Tidak Mendukung } & & Total \\
\hline \multirow[t]{2}{*}{ Sikap } & $\mathrm{f}$ & $\%$ & & $\mathrm{f}$ & $\%$ & & $\mathrm{f}$ & $\%$ \\
\hline & 20 & 50,0 & & 20 & 50,0 & & 40 & 100 \\
\hline
\end{tabular}

sebelum dan setelah diberikan penyuluhan dengan menggunakan kuesioner. Populasi dan sampel dalam penelitian ini adalah ibu-ibu yang memiliki bayi usia $0-10$ bulan yang datang ke posyandu di Desa Sukarapih Kecamatan Sukasari selama periode Agustus 2014.

Pengambilan sampel dilakukan dengan teknik non probability sampling dengan menggunakan menggunakan teknik accidental sampling, yaitu pengambilan sampel dilakukan dengan mengambil kasus atau responden yang kebetulan ada atau tersedia di suatu tempat sesuai dengan konteks penelitian. ${ }^{13}$

Pengambilan data ini dilakukan di Posyandu Desa Sukarapih Kecamatan Sukasari Kabupaten Sumedang, dengan sampel sebanyak 40 orang. Pengambilan data dilakukan selama 3 hari dengan cara sebelumnya menyebarkan undangan kepada para ibu yang memiliki anak usia $0-10$ bulan di lingkup Posyandu Desa Sukarapih Kecamatan Sukasari Kabupaten Sumedang, kemudian para ibu yang datang diberikan informed consent mengenai penelitian ini lalu selanjutnya dilakukan pretest dengan memberikan kuesioner, setelah diberikan pretest para ibu diberikan penyuluhan mengenai imunisasi, kemudian setelah diberikan penyuluhan para ibu diberikan kuesioner kembali untuk dilakukan post test.

\section{Hasil}

Berdasarkan tabel 1. tampak bahwa sebelum diberikan penyuluhan tentang imunisasi responden yang memiliki pengetahuanbaik sebanyak 18 orang $(45,0 \%)$ dan memiliki sikap yang positif yaitu 27 orang $(67,5 \%)$. Berdasarkan tabel 2.tampak bahwa sesudah diberikan penyuluhan tentang efek samping imunisasi yaitu responden cenderung memiliki pengetahuan yang baik sebanyak 26 orang $(65,0 \%)$ dan memiliki sikap cenderung antara positif dan negatif yaitu masing-masing 20 orang (50,0\%). * uji wilcoxon

Berdasarkan tabel 3. tampak bahwa untuk variabel pengetahuan diperoleh nilai $p(0,000)$ $<0,05$ artinya terdapat pengaruh penyuluhan terhadap pengetahuan. Sedangkan untuk variabel sikap diperoleh nilai $p(0,317)>0,05$ artinya tidak terdapat pengaruh penyuluhan terhadap sikap.

Berdasarkan tabel 4.tampak bahwa untuk variabel pengetahuan diperoleh nilai p $(0,000)<0,05$ artinya terdapat pengaruh pengetahuan ibu yang diberikan penyuluhan terhadap sikap ibu dalam pemberian imunisasi.

\section{Pembahasan}

Berdasarkan tabel 1, tampak bahwa sebelum diberikan penyuluhan tentang efek samping imunisasi yaitu responden cenderung memiliki pengetahuan yang baik sebanyak $45,0 \%$ dan yang memiliki pengetahuan kurang sebanyak $12,5 \%$. Hal ini menunjukan bahwa masih ada responden yang kurang mendapatkan informasi mengenai imunisasi sehingga pengetahuannya dikategorikan kurang dan cukup. Pengetahuan merupakan hasil tahu, hal ini terjadi setelah orang melakukan pengindraan terhadap suatu obyek, individu mempunyai dorongan untuk mengerti, dengan pengalamannya memperoleh pengetahuan.,14

Pengetahuan ibu tentang efek samping imunisasi adalah hasil tahu ibu tentang apa saja efek samping jenis imunisasi bagi bayi usia 0-10 bulan. Hal ini penting karena diharapkan para ibu tidak hanya sekedar datang menimbangkan bayinya ke posyandu dan bersedia untuk diimunisasi, tapi juga mengetahui efek samping apa saja yang kemungkinan dapat terjadi bila anak diberikan imunisasi. 
Tabel 3. Pengaruh Penyuluhan terhadap Pengetahuan dan Sikap

\begin{tabular}{lll}
\hline \multicolumn{1}{c}{$\begin{array}{c}\text { Pengaruh } \\
\text { Penyuluhan }\end{array}$} & Z Hitung & P* \\
\hline Pengetahuan & $-4,931$ & 0,000 \\
Sikap & $-1,000$ & 0,317 \\
\hline
\end{tabular}

Tabel 4. Pengaruh Pengetahuan Ibu yang Diberikan Penyuluhan terhadap Sikap Ibu dalam Pemberian Imunisasi

\begin{tabular}{ccc}
\hline $\begin{array}{c}\text { Pengaruh } \\
\text { Penyuluhan }\end{array}$ & Z Hitung & P \\
\hline Pengetahuan & $-5,973$ & 0,000 \\
\hline
\end{tabular}

Salah satu faktor yang memengaruhi pengetahuan adalah karena kekurangan informasi. Pemberian informasi melalui pendidikan dan pelatihan akan meningkatkan pengetahuan, selanjutnya akan menimbulkan kesadaran dan akhirnya seseorang akan melakukan praktek sesuai dengan pengetahuan yang dimiliki, meskipun memerrlukan waktu yang lama ${ }^{4}$ Sikap didefinisikan dengan berorientasi kepada respon adalah suatu bentuk dari perasaan, yaitu perasaaan mendukung atau memihak (favourable) maupun perasaan tidak mendukung (unfavourable) pada suatu objek. Sikap yaitu merupakan kesiapan untuk bereaksi terhadap suatu objek dengan cara-cara tertentu, apabila dihadapkan pada suatu stimuulus yang menghendaki adanya respon, atau juga merupakan suatu pola perilaku, tendenasi atau kesiapan antisipatif untuk menyesuaikan diri dari situasi sosial yang telah terkondisikan. ${ }^{17}$ Azwar mengatakan bahwa sikap memengaruhi praktek lewat suatu proses pengambilan keputusan yang teliti dan beralasan dan dampaknya terbatas yang berarti bahwa seseorang akan melakukan suatu perbuatan apabila ia memandang perbuatan itu positif dan bila ia percaya bahwa orang lain ingin agar ia melakukannya. ${ }^{4}$ Dalam penelitian ini sikap responden yaitu ibuibu yang mempunyai bayi usia 0-10 tahun pada umumnya memiliki sikap mendukung, namun tidak sedikit juga ibu-ibu yang justru memiliki sikap sebaliknya yaitu tidak mendukung, hal ini bisa disebabkan karena berbagai faktor, salah satunya adalah karena informasi yang didapat oleh ibu, ataupun lingkungan sekitar ibu. Oleh sebab itu, sebagai tenaga kesehatan yang berhubungan langsung degan ibu bayi ataupun balitanya yang ada di masyarakat harus memberikan informasi yang cukup khususya tentang imunisasi dasar lengkap, baik jenis dan manfaatnya maupun kemungkinan reaksi yang ditimbulkan pada tubuh bayi. Diharapkan dengan adanya informasi yang cukup jelas maka ibu bayi tidak lagi ada yang menunjukan sikap negatif terhadap program imunisasi, sehingga ke depannya hasil yang dicapai pada program imunisasi tersebut bisa meningkatkan angka cakupan imunisasi menjadi lebih tinggi

Berdasarkan tabel 2. juga, tampak bahwa sesudah diberikan penyuluhan tentang efek samping imunisasi yaitu responden cenderung memiliki pengetahuan yang baik sebanyak $65,0 \%$ dan yang memiliki pengetahuan kurang menjadi tidak ada, sehingga ada $35,0 \%$ di kategori cukup. Setelah diberikan penyuluhan mengenai efek samping imunisasi, didapatkan hasil tidak ada lagi ibu yang memiliki pengetahuan kurang, hal ini karena ibu telah diberikan informasi mengenai efek samping imunisasi. Informasi yang diperoleh baik dari pendidikan formal maupun non formal dapat memberikan pengaruh jangka pendek (immediate impact) sehingga menghasilkan perubahan atau peningkatan pengetahuan. ${ }^{15-16}$

Sikap dibentuk melalui proses belajar sosial, yaitu proses dimana individu memperoleh informasi tingkah laku, atau sikap baru dari orang lain. Ibu yang memiliki anak usia 8-10 bulan tentu lebih berpengalaman dibandingkan ibu lainnya yang memiliki anak dibawah usia 8 bulan, ibu yang memiliki anak usia 8-10 bulan telah mendapatkan pembelajaran pengondisian instrumental dan belajar melalui pengamatan, pengondisian instrumental yang dimaksud adalah proses pembelajaran terjadi ketika suatu perilaku mendatangkan hasil yang menyenangkan bagi seseorang, maka perilaku tersebut akan diulang kembali. Hal itu juga yang terjadi pada ibu saat memutuskan untuk mengimunisasikan anaknya, ibu melihat bahwa anaknya setelah diimunisasi menjadi sehat, maka hal tersebut adalah hasil yang menyenangkan bagi ibu sehingga ia mau kembali untuk mengulang imunisasi bagi anaknya. ${ }^{18}$ Belajarmelalui pengamatanyang dimaksud adalah proses pembelajaran dengan cara mengamati perilaku orang lain, kemudian dijadikan sebagai contoh untuk berperilaku serupa. Dalam keseharian, banyak sikap yang terbentuk karena aktif mengamati berita-berita dan gambar melalui koran, televisi, majalah dan media lainnya. ${ }^{18-19}$ Setelah diberikan penyuluhan mengenai imunisasi, sikap ibu tidak banyak berubah, hal ini dapat disebabkan oleh faktor-faktor yang memengaruhi pembentukan sikap yaitu pengalaman pribadi, kebudayaan, orang lain yang dianggap penting, dan media massa. Dalam penelitian ini tidak menganalisis lebih jauh 
mengenai faktor tersebut. Meskipun pengetahuan ibu cenderung baik namun sikap adalah respon tertutup seseorang terhadap suatu stimulus atau objek. Notoatmodjo membagi sikap dalam 4 tingkatan, ibu yang diberikan penyuluhan sikapnya berada dalam tingkatan pertama yaitu menerima, ibu mau dan memperhatikan stimulus yang diberikan tetapi ia tidak merespon, menghargai dan bertanggungjawab sehingga penyuluhan yang diberikan tidak terlalu memberikan arti bagi perubahan sikap ibu. ${ }^{5,19}$

Hasil analisis data sesuai tabel 3. dengan menggunakan uji Wilcoxon tampak bahwa untuk variabelpengetahuandiperolehnilaip0,000artinya terdapat pengaruh penyuluhan terhadap pengetahuan. Selanjutnya dapat disimpulkan bahwa penyuluhan memiliki pengaruh terhadap peningkatan pengetahuan responden mengenai efek samping imunisasi. Sedangkan untuk variabel sikap diperoleh nilai $\mathrm{p} 0,317$ artinya tidak terdapat pengaruh penyuluhan terhadap sikap.

Dalam penelitian ini peneliti memberikan penyuluhan kepada ibu-ibu yang mempunyai bayi usia $0-10$ bulan mengenai efek samping imunisasi, didapatkan hasil bahwa ternyata penyuluhan berpengaruh terhadap pengetahuan ibu tapi tidak berpengaruh kepada sikap. Meskipun dalam teori menyebutkan bahwa sikap sejalan dengan pengetahuan yang didapatkan, hasil penelitian menunjukan tidak terdapat pengaruh penyuluhan terhadap sikap. Perubahan sikap ini kemungkinan sejalan dengan teori yang dikemukakan oleh Kelman, berdasarkan teori tiga proses perubahan Kelmanyaitu kesedian (compliance), identifikasi (identification), dan internalisasi (internalization). ${ }^{20}$ Disini tidak terdapat kesediaan ibu untuk merubah sikap meskipun sudah diberikan penyuluhan, kemudian untuk proses identifikasi yang terjadi adalah ibu meniru perilaku atau sikap seseorang atau sikap kelompok lain dikarenakan sikap tersebut sesuai dengan apa yang dianggapnya sebagai bentuk hubungan yang menyenangkan antara dia dengan pihak lain termaksud, maksudnya disini bisa berkaitan dengan lingkungan, ataupun pengaruh orang lain yang dianggap penting, sama halnya juga dengan internalisasi terjadi apabila individu menerima pengaruh dan bersedia bersikap menuruti pengaruh itu dikarenakan sikap tersebut sesuai dengan sistem nilai yang dianutnya. ${ }^{20}$

Penekanan konsep penyuluhan kesehatan lebih pada upaya mengubah perilaku sasaran agar berperilaku sehat terutama pada aspek kognitif (pengetahuan dan pemahaman sasaran), sehingga pengetahuan sasaran penyuluhan telah sesuai dengan yang diharapkan oleh penyuluh kesehatan maka penyuluhan berikutnya akan dijalankan sesuai dengan program yang telah direncanakan..$^{21}$
Penyuluhan kesehatan yang dilakukan merupakan bentuk dari persuasi. Persuasi merupakan usaha pengubahan sikap individu dengan memasukan ide, fikiran, pendapat, dan bahkan fakta baru lewat pesan-pesan komunikatif. Pesan yang disampaikan dengan sengaja dimaksudkan untuk menimbulkan kontradiksi dan inkonsistensi diantara komponen sikap individu atau diantara sikap dan perilakunya sehingga mengganggu kestabilan sikap dan membuka peluang terjadinya perubaan yang diinginkan. Pada penilitian kali ini perubahan sikap tidak sesuai dengan yang diharapkan. ${ }^{20}$ Effendy menyatakan bahwa penyuluhan kesehatan merupakan kegiatan pendidikan yang dilakukan dengan cara menyebarkan pesan, menanamkan keyakinan, sehingga masyarakat tidak saja sadar, tahu dan mengerti, tetapi juga mau dan bisa melakukan suatu anjuran yang ada hubungannya dengan kesehatan. ${ }^{15}$ Menurut teori, pemberian informasi melalui pendidikan dan pelatihan akan meningkatkan pengetahuan, selanjutnya akan menimbulkan kesadaran dan akhirnya seseorang akan melakukan praktek sesuai dengan pengetahuan yang dimiliki, meskipun memerlukan waktu yang lama. ${ }^{4}$ Sikap merupakan kesediaan bereaksi terhadap suatu hal yang disertai dengan kecenderungan untuk bertindak sesuai dengan objek itu. Sikapdapat merupakan suatu sikap pandangan tetapi dalam hal itu masih berbeda dengan suatu pengetahuan yang dimiliki orang. Pengetahuan mengenai suatu objek tidak sama dengan sikap terhadap objek itu. Pengetahuan saja belum menjadi penggerak, sebagaimana pada sikap. Pengetahuan mengenai suatu objek baru menjadi sikap terhadap objek tersebut apabila pengetahuan itu disertai dengan kesiapan untuk bertindak sesuai dengan pengetahuan terhadap objek itu. ${ }^{22}$

Tidak berubahnya sikap sesuai dengan yang diharapkan setelah dilakukan penyuluhan berkaitan dengan teori efektivitas komunikasi yang dikatakan Azwar. Pada dasarnya, suatu komunikasi akan lebih efektif apabila disampaikan secara langsung berhadapan. Menurut penelitian, tekhnik komunikasi yang efektif adalah dengan mengemukakan kesimpulan komunikasi secara eksplisit kepada subjek yang sikapnya hendak diubah, dengan mengulangulang argumentasi yang mendukung sikap yang dituju dan banyaknya pengulangan pesan yang optimal adalah tiga kali. Dalam penelitian ini penyampaian pesan yang dilakukan yaitu penyuluhan hanya dilakukan satu kali sehingga sejalan dengan teori bahwa hal tersebut tidak akan mengubah sikap sesuai dengan yang diharapkan. ${ }^{20}$

Untuk dapat diterima oleh target, penyampaian pesan persuasif harus dilakukan dengan 
memperhatikan batas penerimaan (latitude of acceptance), batas tanpa ketentuan (latitude of noncommitment), dan batas penolakan (latitude of rejection) yang ada bagi setiap macam sikap. Batas penerimaan, batas tanpa ketentuan, dan batas penolakan dipengaruhi oleh tiga hal, yakni keterlibatan individu, kredibilitas komunikator, dan perbedaan posisi sikap individu. Semakin tinggi kredibilitas komunikator, akan semakin lebar batas penerimaan individu sehingga pesan akan mudah diterima dan sikap tidak akan sulit berubah. Bila sikap yang hendak diubah menyangkut masalah yang punya arti sangat relevan bagi individu artinya individu sangat terlibat, maka batas penolakanlah yang akan melebar dan batas tanpa ketentuan akan menyempit sehingga tidaklah mudah untuk mengadakan pengubahan sikap. ${ }^{20}$

Berdasarkan uraian diatas, sikap yang hendak diubah dalam penelitian ini menyangkut masalah yang punya arti sangat relevan bagi individu yakni mengenai imunisasi, sehingga sesuai dengan teori efektivitas komunikasi, ketika individu sangat terlibat, batas penolakan akan semakin melebar dan batas tanpa ketentuan akan menyempit sehingga pengubahan sikap tidaklah mudah. ${ }^{20}$

Hasil analisis data sesuai tabel 4 dengan menggunakan uji wilcoxon pengaruh pengetahuan ibu yang diberikan penyuluhan terhadap sikap ibu dalam pemberian imunisasi diperoleh nilai $\mathrm{p}$ sebesar 0,000 . Hal ini menunjukkan bahwa terdapat pengaruh yang signifikan pengetahuan ibu yang diberikan penyuluhan terhadap sikap ibu dalam pemberian imunisasi.

Pengetahuan atau knowledge adalah hal tahu atau pemahaman akan sesuatu yang bersifat spontan tanpa mengetahui seluk beluknya secara mendalam. Walgito berpendapat pengetahuan merupakan hasil tahu, hal ini terjadi setelah orang melakukan pengindraan terhadap suatu obyek, individu mempunyai dorongan untuk mengerti, dengan pengalamannya memperoleh pengetahuan ${ }^{4,14}$ Menurut teori, pemberian informasi melalui pendidikan dan pelatihan akan meningkatkan pengetahuan, selanjutnya akan menimbulkan kesadaran dan akhirnya seseorang akan melakukan praktek sesuai dengan pengetahuan yang dimiliki, meskipun memerlukan waktu yang lama. ${ }^{4}$ Sikap merupakan kesediaan bereaksi terhadap suatu hal yang disertai dengan kecenderungan untuk bertindak sesuai dengan objek itu. Sikapdapat merupakan suatu sikap pandangan tetapi dalam hal itu masih berbeda dengan suatu pengetahuan yang dimiliki orang. Pengetahuan mengenai suatu objek tidak sama dengan sikap terhadap objek itu. Pengetahuan saja belum menjadi penggerak, sebagaimana pada sikap.
Pengetahuan mengenai suatu objek baru menjadi sikap terhadap objek tersebut apabila pengetahuan itu disertai dengan kesiapan untuk bertindak sesuai dengan pengetahuan terhadap objek itu. ${ }^{22}$

Dalam jurnal berjudul Pengaruh Pengetahuan Terhadap Sikap Ibu Mengenai Imunisasi Ulangan Difetria-Tetanus oleh Yenny, Eddy dan Nanan, hasilnya menunjukan pengaruh positif pengetahuan terhadap sikap ibu murid kelas I SD mengenai imunisasi ulangan difteria dan tetanus. Pengetahuan yang baik akan meningkatkan sikap positif ibu untuk secara mandiri melakukan imunisasi ulangan difteria dan tetanus pada anaknya. ${ }^{23}$

Dalam penelitian ini pengetahuan memiliki hubungan yang signifikan untuk mempengaruhi sikap ibu dalam imunisasi, meskipun jika dilihat kembali sikap ibu setelah diberikan penyuluhan imunisasi tidaklah meningkat hal ini dapat dilihat sesuai dengan teori bahwa pengetahuan saja belum menjadi penggerak untuk merubah sikap. Pengetahuan mengenai suatu objek baru menjadi sikap terhadap objek tersebut apabila pengetahuan itu disertai dengan kesiapan untuk bertindak sesuai dengan pengetahuan terhadap objek itu. ${ }^{22}$ Berdasarkan teori tiga proses perubahan Kelman, yaitu 1. Kesedian; disini tidak terdapat kesediaan ibu untuk merubah sikap meskipun pengetahuan ibu adalah baik, kemudian 2. Identifikasi; untuk proses identifikasi yang terjadi adalah ibu meniru perilaku atau sikap seseorang atau sikap kelompok lain dikarenakan sikap tersebut sesuai dengan apa yang dianggapnya sebagai bentuk hubungan yang menyenangkan antara dia dengan pihak lain termaksud, maksudnya disini bisa berkaitan dengan lingkungan, ataupun pengaruh orang lain yang dianggap penting, dan 3. Internalisasi; internalisasi terjadi apabila reponden menerima pengaruh dan bersedia bersikap menuruti pengaruh itu dikarenakan sikap tersebut sesuai dengan sistem nilai yang dianutnya. ${ }^{20}$

Dapat disimpulkan pada penelitian ini bahwa meskipun pengetahuan ibu setelah diberikan penyuluhan signifikan terhadap sikap, tetapi ada faktor-faktor lain yang mempengaruhi sikap ibu sehingga akhirnya sikap responden tidak mendukung karena kuat pengaruh dari pengalaman pribadi, pengaruh orang lain yang dianggap penting, pengaruh kebudayaan, media massa, lembaga pendidikan dan lembaga agama, dan pengaruh faktor emosional, dimana dalam hal ini tidak diteliti.

Oleh karena itu disarankan kepada para ibu diharapkan dapat lebih meningkatkan wawasan tentang imunisasi melalui fasilitas tenaga kesehatan, ataupun buku-buku yang ada. Selain itu juga kepada profesi bidan diharapkan dapat menjadi masukan bagi pemberi 
pelayanan kebidanan untuk meningkatkan kualitas pelayanan dan memberikan pelayanan yang baik bagi pengguna pelayanan kebidanan, khususnya dalam memberikan pendidikan kesehatan tentang pemberian imunisasi dan efek sampingnya.Institusi kesehatan diharapkan dapat meningkatkan promosi kesehatankepada para ibu tentang pentingnya pemberian imunisasi secara lengkap terutama untuk bayi sebelum usia 1 tahun.

\section{Daftar Pustaka}

1. Keputusan Menteri Kesehatan Republik Indonesia Nomor: 482/MENKES/SK/V/2010 Tentang Gerakan Akselarasi Imunisasi Nasional Universal Child Immunization 2010-2014 (GAIN UCI 2010-2014).

2. BAPPENAS. Laporan Pencapaian Tujuan Pembangunan Milenium Di Indonesia 2011. Jakarta: Kementerian Perencanaan Pembangunan Nasional / Badan Perencanaan Pembangunan Nasional (BAPPENAS); 2012.

3. Badan Penelitian dan Pengembangan Kesehatan Kementrian Kesehatan RI: RISKESDAS 2013.

4. Palupi AW. Pengaruh Penyuluhan Imunisasi Terhadap Peningkatan Pengetahuan Dan Sikap Ibu Tentang Imunisasi Dasar Lengkap Pada Bayi Sebelum Usia 1 Tahun. Surakarta: Universitas Sebelas Maret; 2011.

5. Notoadmodjo S. Pengantar Pendidikan Ilmu Kesehatan dan Ilmu Perilaku Kesehatan. Yogyakarta: Andi Offset; 2003.

6. Widayati S. Hubungan Tingkat Pengetahuan Ibu Tentang Imunisasi Polio Dengan Perilaku Pasca Imunisasi Polio Pada Bayi Di Puskesmas Sukoharjo. Surakarta: Universitas Sebelas Maret; 2009.

7. Departemen Kesehatan dan Kesejahteraan Sosial RI. Gerakan Terpadu Nasional Penanggulangan Tuberkulosis Nasionan (Gedurnas TB). Jakarta: Depkes \& Kesos; 2000.

8. CDC. Guidelines for the investigation of contacts of persons with infectious tuberculosis.: Recommendations from the National tuberculosis Controllers Associations ann CDC - MMWR Recommendation Report; 2005.

9. CDC. Preventing tetanus,diphteria, and pertusis amongadolescents: us of tetanus toxoid, reduced diphteria toxoid and acellular pertucis vaccines: recomendations of the Adisory Committee of Immunization Practices (ACIP) MMWR Reccom; 2006.

10. AS L, BJ MM. Practice Guidelines Committe, American Assotiation for the Study of Liver Disease (AASLD). Chronic hepatitis B: Uptade of recommendations Hepatology; 2004.

11. Satgas Imunisasi IDAI. Pedoman Imunisasi Di Indonesia: Sari Pediatri; 2008.

12. Syarifudin, Hamidah. Kebidanan Komunitas. Jakarta: EGC; 2007.

13. Notoadmodjo S. Metodologi Penelitian Kesehatan. Jakarta: Rineka Cipta; 2010.

14. Nurbayani. Pengertian Ilmu Pengetahuan, Kebudaaan, Teknologi dan Moralitas. Available from: http://file.upi.edu/Direktori/ FPIPS/M K D U/197007111994032SITI NÜR B A Y A N K/MATER I

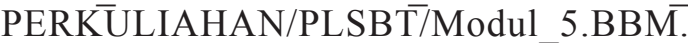
Lanjt.pdf.

15. Notoatmodjo S. Ilmu Kesehatan Masyarakat (Prinsip-prinsip Dasar). Jakarta: Rineka Cipta; 2003.

16. Yusnipah Y. Tingkat Pengetahuan Keluarga Dalam Merawat Pasien Halusinasi Di Poliklinik Psikiatri Rumah Sakit Marzoeki Mahdi Bogor. Depok: Universitas Indonesia; 2012.

17. Rahayuningsih SU. Psikologi Umum 2 2008. Available from: http://nurul q.staff. gunadarma.ac.id/Downloads/files/9095/ bab1-sikap-1.pdf.

18. Sarwono SW, Meinarno EA, Takwin B, Wibowo I, Halida R, Mashoedi SF, et al. Psikologi Sosial. Depok: Salemba Humanika; 2009.

19. Phenomena Pratama Consulting Sikap; Pengertian, Definisi, dan Faktor yang Memengaruhi2012.

20. Azwar S. Sikap Manusia Teori Dan Pengukurannya. Yogyakarta: Pustaka Pelajar Offset; 1995.

21. Universitas Sumatera Utara. 2011 [cited $2014 \quad 1$ September]; Available from: http://repository.usu.ac.id/ bitstream/123456789/27931/3/Chapter\%20 II.pdf.

22. Gerungan WA. Psikologi Sosial. Bandung: Refika Aditama; 2004.

23. Purnama Y, Fadlyana E, Sekarwana N. Pengaruh Pengetahuan Terhadap Sikap Ibu Mengenai Imunisasi Ulangan DifetriaTetanus. Sari Pediatri. 2008;2. 